\title{
A Study on Factors Causing Cost Overrun of Construction Projects in Sarawak, Malaysia
}

\author{
Ahmed Mohammed Kamaruddeen ${ }^{1, *}$, Chang Foh Sung ${ }^{2}$, Wahida Wahi ${ }^{2}$ \\ ${ }^{1}$ School of Business, Skyline University College Sharjah, United Arab Emirates \\ ${ }^{2}$ Quantity Surveying Programme, School of Built Environment, University College of Technology Sarawak, Malaysia
}

Received June 11, 2019; Revised March 25, 2020; Accepted May 13, 2020

Copyright $\bigcirc 2020$ by authors, all rights reserved. Authors agree that this article remains permanently open access under the terms of the Creative Commons Attribution License 4.0 International License.

\begin{abstract}
Cost overrun is one of the issues confronting the construction industry. Most of the construction projects in Malaysia have experienced cost overrun of 5 to $10 \%$ of the total contract sum. In examining the east Malaysia scenario, this study aims to identify the factors causing cost overrun of construction projects in Sarawak. A quantitative approach was adopted in carrying out the research. Stratified random sampling was adopted to obtain data from Grade 7 contracting companies and quantity surveying firms operating in Sarawak. Descriptive statistics (measures of central tendency) and the Relative Importance Index (RII) were used to analyze the data. The most significant factors identified were the shortage of material, lack of plant and spare parts of equipment, acceleration required by clients, change of work scope or changes in material specification by clients, mistakes during construction, fluctuation in prices of raw materials, shortage of workforce, lack of skilled labour, poor project management, poor cost control and awarding of a contract to the lowest bidders. This study complements the existing knowledge on the factors causing cost overrun in the Malaysian construction industry. Hence, clients, contractors, project managers, quantity surveyors, and other project participants will be aware of the factors considered while planning for a project.
\end{abstract}

Keywords Cost Overrun, Construction Industry, Construction Projects, Sarawak, Malaysia

\section{Introduction}

The construction industry contributes positively to the growth of the socio-economic status of a country, thus leading to the improvement of the people's standard of living. However, one of the major problems hampering the successful completion of most projects in the construction industry is a cost overrun. Therefore, to consider a project as being successful by any construction company, Olawale and Sun [1] state that the three main elements, time, cost and quality, must be achieved. Cost overrun of construction projects is not a new issue across the construction industries and can be seen as a common issue across project sites. According to Ameh et al. [2], only 16\% of 8,000 construction projects in Nigeria were completed within budget, time and quality in 1994. Flyvbjerg's et al. [3] research further shows that most of the projects in the construction industry globally are not completed within the project cost. The research finding implies that only a few projects are completed within the estimated budget. Hence, cost overrun of construction projects can be viewed as a global issue that requires collective efforts from all the construction industry players [4].

Studies such as Memon et al. [5], Rahman et al. [6], and Memon et al. [7] have examined the issue of cost overrun in the Malaysian construction industry. However, these studies do not explicitly focus on the eastern region of Malaysia; they instead focus on the Malaysian Peninsula. For instance, Rahman et al. [6] identified the significant factors causing cost overruns in large construction projects in Malaysia. There was no indication of inclusion or exclusion of the eastern region of Malaysia in their study. Shehu et al. [8] is another related study which explored the construction cost performance of projects across Malaysia. Their study found that more than half of Malaysian construction projects (55\%) experienced cost overruns and that public sector project performed better than private sector projects. However, the focus of their study was not to identify the factors causing cost overrun of construction projects in Malaysia. In Shehu et al. [8] study, the unit of analysis was made up of various projects. However, only one project was chosen from Sarawak State, representing $0.3 \%$ of the total sampled projects across Malaysia. Besides, the authors acknowledge that their findings might not necessarily be generalized to all geographical locations 
in Malaysia. Memon et al. [5] identified several factors causing cost overrun of the projects in the Malaysian construction industry. Their findings suggest that design issues, financial resources management, project management, site management, information technology, material, machinery, labour resources and external factors are the factors causing cost overrun.

In terms of land size, Sarawak State is the largest of the 13 states in Malaysia. Its land size is almost the same as the land size of Peninsular Malaysia. While sharing a border with Indonesia and Brunei, it is located in the northwest of Borneo Island. This study covers Sarawak State only due to the following reasons: firstly, the state is separated from Peninsular Malaysia by the South China Sea with a distance of 600 kilometres. Secondly, Sarawak has autonomy in immigration and land matters. The state's control of people's movements, as well as goods and services in and out of the country, might have an impact on the importation of construction materials and hiring foreign workers to work in Sarawak. The effect of immigration policy, such as approval of work permits to foreigners, can impact on the construction time and indirectly affect the construction cost. Third, Sarawak is divided into three regions: coastal lowlands comprising peat swamp as well as narrow deltaic and alluvial plains, a vast area of undulating hills of 300 meters, and the mountain highlands extend to the Kalimantan border. The geographical location of Sarawak implies that most construction and building materials are transported into the state by sea. The logistics involved in importing building materials into Sarawak State might have an impact on the construction projects in the state.

Cost overrun of construction projects has become a frequent occurrence in the Malaysia construction industry. According to Memon et al. [5], 89\% of the construction projects in Malaysia are facing cost overrun issues. It was found that $5-10 \%$ cost overrun has become a recurring decimal in the Malaysian construction industry. The delay of the construction works also resulted in a cost overrun. Understanding the factors contributing to the cause of cost overrun of construction projects among the project players will be required as a stepping stone in minimizing cost overruns [8]. Hence, there is a need for examining the factors influencing the cost overrun of construction projects in the Sarawak State of Malaysia.

\section{Factors Causing Cost Overrun in the Construction Industry}

There are several types of factors causing cost overrun of construction projects. Researchers have grouped the factors into several categories. For example, Rahman et al. [6] grouped the factors into seven: contractor's site management-related factors, design and documentation related factors, financial management-related factors, information and communication technology-related factors, labour management-related factors, materials and machinery related factors and project management \& contract administrative-related factors. However, Baloyi and Bekker [9] used a three-broad category in determining the factors that caused cost overrun in the 2010 FIFA World Cup stadia in South Africa. The three broad categories are client-related factors, contractor related factors and external related factor. This paper adopts the three broad categories used by Baloyi and Bekker [9]. The reason is that the three broad categories can accommodate other classifications used in previous studies [6].

\subsection{Client Related Factors}

The client-related factors causing cost overrun are the factors attributed to the client and the consultants representing the client [9]. The client-related factors are presented in Table 1.

Table 1. Client Related Factors Causing Cost Overrun on Construction Project

\begin{tabular}{|l|l|l|}
\hline No & Client related factors & References \\
\hline 1 & Contract awarded to the lowest bidder & {$[9-12]$} \\
\hline 2 & $\begin{array}{l}\text { Poor project management and poor cost } \\
\text { control }\end{array}$ & $\begin{array}{l}{[2,7,10,11,} \\
13]\end{array}$ \\
\hline 3 & $\begin{array}{l}\text { The long period between design and time of } \\
\text { bidding or tendering }\end{array}$ & {$[2,10,11,12]$} \\
\hline 4 & Inaccurate preparation of cost estimates & {$[9-12]$} \\
\hline 5 & Incorrect planning & {$[2,10,11]$} \\
\hline 6 & Client's late contract award & {$[9]$} \\
\hline 7 & $\begin{array}{l}\text { Change of work scope or changes in } \\
\text { material specification by client }\end{array}$ & {$[2,9,12,13]$} \\
\hline 8 & Waiting for information & {$[10]$} \\
\hline 9 & Monthly payment difficulties & {$[7,10,13]$} \\
\hline 10 & Slow decision making & {$[10]$} \\
\hline 11 & Design and documentation issues & {$[7,13]$} \\
\hline 12 & Inappropriate procurement & {$[12]$} \\
\hline 13 & Acceleration required by the client & {$[12]$} \\
\hline 14 & Delay of drawings and site instructions & {$[12]$} \\
\hline & & \\
\hline
\end{tabular}

Sources: $[9,11]$

\subsection{Contractor Related Factors}

Table 2. Contractor related factors causing cost overrun on the construction project

\begin{tabular}{|l|l|l|}
\hline No & Contractor related factors & References \\
\hline 1 & Lack of skilled labour & {$[9,10]$} \\
\hline 2 & Mistakes during construction & {$[10,12,13]$} \\
\hline 3 & $\begin{array}{l}\text { Inadequate or frequent breakdowns of } \\
\text { construction plant and equipment }\end{array}$ & {$[7,10,13]$} \\
\hline 4 & Contractor's financial difficulties & {$[10]$} \\
\hline 5 & Labour (human) resource & {$[2,7,13]$} \\
\hline 6 & Poor site management & {$[2,7,12,13]$} \\
\hline 7 & Contractor's workload & {$[2,13]$} \\
\hline 8 & Incompetent subcontractor & {$[12]$} \\
\hline
\end{tabular}


Sources: [9-10]

As shown in Table 2, the contractor related cost overrun factors are those factors that are attributed to the contractor's organization [9].

\subsection{External Factors}

Cost overrun factors that are beyond the control of the client and the contractors are classified as part of the external factors [9]. Table 3 presents the list of cost overrun antecedents that can be attributed to external factors.

Table 3. External factors causing cost overrun on the construction project

\begin{tabular}{|c|c|c|}
\hline No & External factors & References \\
\hline 1 & Fluctuation in prices of raw materials & {$[2,9-11]$} \\
\hline 2 & Unstable cost of manufactured & {$[11,14]$} \\
\hline 3 & The high cost of machinery & {$[11,15]$} \\
\hline 4 & Additional work & {$[2,11]$} \\
\hline 5 & Inappropriate government policies & {$[2,11]$} \\
\hline 6 & Shortage of workforce & {$[2,9,10,13]$} \\
\hline 7 & Project complexity & {$[9,13]$} \\
\hline 8 & Increase in labour cost & [9] \\
\hline 9 & Delays in work approval & {$[10]$} \\
\hline 10 & Delays in inspection and testing of work & {$[10]$} \\
\hline 11 & Shortage of material & {$[2,7,10]$} \\
\hline 12 & Shortage of plant and equipment's parts & {$[10]$} \\
\hline 13 & Material procurement & {$[7,13]$} \\
\hline 14 & Imported material & {$[10]$} \\
\hline 15 & Late delivery of materials and equipment & {$[2,10]$} \\
\hline 16 & Economic stability & $\begin{array}{lll}{[2,} & 10,12, \\
13] & \end{array}$ \\
\hline 17 & $\begin{array}{l}\text { Inadequate site investigation or unexpected } \\
\text { site condition }\end{array}$ & {$[10,12,13]$} \\
\hline 18 & Weather & $\begin{array}{lll}{[2,} & 10, & 12, \\
13] & & \end{array}$ \\
\hline 19 & Poor communication between all parties & {$[2,12,13]$} \\
\hline 20 & $\begin{array}{l}\text { Disputes among the parties involved in the } \\
\text { project }\end{array}$ & {$[2,13]$} \\
\hline 21 & Fuel shortages & {$[13]$} \\
\hline 22 & Site accidents & [13] \\
\hline 23 & Project location & {$[2,13]$} \\
\hline 24 & $\begin{array}{l}\text { Domination of the construction industry by } \\
\text { foreign firms and aids }\end{array}$ & {$[2,16]$} \\
\hline 25 & Absence of construction cost data & {$[2]$} \\
\hline 26 & Level of competition & {$[2,17]$} \\
\hline 27 & Social and cultural impacts & {$[2,18]$} \\
\hline 28 & Labour nationality & {$[2]$} \\
\hline 29 & Information and communication technology & {$[7]$} \\
\hline
\end{tabular}

Sources: [9-12]

\section{Materials and Method}

\subsection{Research Approach}

The factors causing cost overrun of construction projects were identified in the literature and were categorized into client, contractor and external related factors. This study adopted a quantitative approach in carrying out the research and used a stratified simple random sampling technique to collect the relevant data. The population for this study comprised contractors' companies that registered with the Construction Industry Board Malaysia (CIDB) and the quantity surveying firms that registered with the Board of Quantity Surveyors in Malaysia. A total of 25 quantity surveying firms and 201out of the 420 Grade 7 contractors participated in the survey.

With reference to Enshassi's et al. [19] prescription, this research used a 5-point Likert scale ranging from 1 to 5 as follows: 1 = Not significant, 2 = Slightly significant, 3 = Moderately significant, $4=$ Very significant, and $5=$ Extremely significant. Respondents were requested to rate a list of 35 factors causing cost overruns from 1 to 5 .

\subsection{Data Analysis}

It is a known practice among scholars to use the Relative Importance Index(RII) for researches that relate to the identification of factors influencing cost overrun Rafidah et al. [20]; Yehiel [21]; Gündüz et al. [22]; Hemanta [23]. Following the pattern adopted by Kometa et al. [24]; Sambasivan and Soon [25], who used the RII analysis to determine the relative importance of various delay factors, this research also adopted the same analysis to determine causes of cost overrun in the Sarawak State of Malaysia. The data collected from the respondents were analyzed using the Statistical Package for Social Science (SPSS) version 22 to determine the descriptive statistics. Besides, the Relative Importance Index (RII) was adopted in this study. RII values were obtained using the formula in equation 1 with the aid of Microsoft Excel.

$$
\mathrm{RII}=\frac{\sum W}{(A * N)}
$$

Where RII is relative importance index, $\mathrm{W}$ is the weightage assigned to each factor by the respondent on a scale of one to five. A is the highest weight (5 in this research), and $\mathrm{N}$ is the total number of the sample. Akadiri's [26] level of importance was used to interpret the RII values obtained as follows: high importance (RII = $0.8-1)$, high-medium importance $(\mathrm{RII}=0.6-0.8)$, medium importance $(\mathrm{RII}=0.4-0.6)$, medium-low importance $(\mathrm{RII}=$ $0.2-0.4)$ and low importance $(\mathrm{RII}=0-0.2)$. 


\section{Results}

Figure 1 depicts the response rate of this paper:

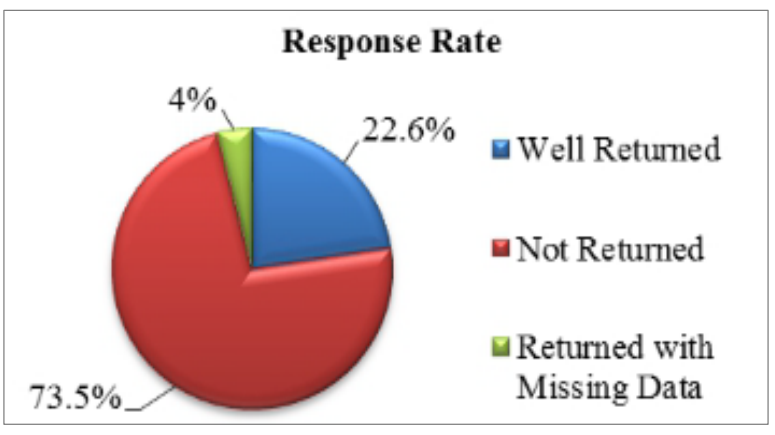

Figure 1. Response rate

Table 4. Respondents' profile

\begin{tabular}{|c|c|c|}
\hline GENERAL INFORMATION & FREQUENCY & $\%$ \\
\hline \multicolumn{3}{|l|}{ Type of Organization } \\
\hline QS Consultant Firm & 8 & 15.69 \\
\hline Contracting companies & 43 & 84.31 \\
\hline \multicolumn{3}{|l|}{ Gender } \\
\hline Male & 27 & 52.94 \\
\hline Female & 24 & 47.06 \\
\hline \multicolumn{3}{|l|}{ Age } \\
\hline $20-25$ & 23 & 45.10 \\
\hline $26-30$ & 6 & 11.76 \\
\hline $31-35$ & 11 & 21.57 \\
\hline $36-40$ & 4 & 7.84 \\
\hline 41 and above & 7 & 13.73 \\
\hline \multicolumn{3}{|l|}{ Ethnic } \\
\hline Malay & 3 & 5.88 \\
\hline Chinese & 42 & 82.35 \\
\hline Indian & 6 & 11.76 \\
\hline Others & 0 & 0.00 \\
\hline \multicolumn{3}{|l|}{ Position } \\
\hline Project director & 3 & 5.88 \\
\hline Project manager & 4 & 7.84 \\
\hline Project coordinator & 1 & 1.96 \\
\hline Architect & 1 & 1.96 \\
\hline Engineer & 25 & 49.02 \\
\hline Quantity surveyor & 17 & 33.33 \\
\hline Others & 0 & 0.00 \\
\hline \multicolumn{3}{|l|}{ Level of education } \\
\hline Diploma & 15 & 29.41 \\
\hline Degree & 35 & 68.63 \\
\hline Master & 1 & 1.96 \\
\hline Doctorate & 0 & 0.00 \\
\hline Others & 0 & 0.00 \\
\hline \multicolumn{3}{|l|}{ Experience } \\
\hline Less than two years & 21 & 41.18 \\
\hline $2-4$ years & 7 & 13.73 \\
\hline $4-6$ years & 7 & 13.73 \\
\hline 6 years and above & 16 & 31.37 \\
\hline
\end{tabular}

A total of 60 copies of the questionnaire out of 226 were returned. However, nine (9) copies of the questionnaire were incomplete and cannot be used for the analysis. Thus the overall percentage (Fig. 1 ) used for the analysis was $22.6 \%$ 
out of which the contractor firms accounted for $19 \%$ and the quantity surveying firms accounted for $3.6 \%$. According to Cheung et al. [27], 14.1\% of response rate in the construction industry is still considered acceptable. Therefore, the response rate $(22.6 \%)$ of the present study is considered an acceptable one. Table 4 presents the demographic profile of the respondents. $84.31 \%$ of the respondents were contracting companies, and the remaining 15.69 were QS consulting firms. The male respondents were $52.94 \%$, and females were $47.69 \%$. $82.35 \%$ were Chinese, $11.76 \%$ and $5.88 \%$ were Indians and Malays, respectively.

Table 5 presents the results of the relative importance index of the factors causing cost overrun of construction projects in Sarawak, Malaysia. The factors are presented in the following descending order. In essence, the shortage of material was ranked first. It was followed by shortage of plant and spare parts of equipment, acceleration required by the client, change of work scope or changes in material specification by the client, mistakes during construction, fluctuation in prices of raw materials, shortage of workforce, lack of skilled labour, poor project management and poor cost control. Contract awarded to the lowest bidder was ranked tenth. Delays in work approval and unstable cost of the manufactured product were both ranked eleventh, additional work and breakdowns of construction plant \& equipment were ranked fourteenth. Waiting for information was ranked thirty-fifth. Out of the thirty-five factors, the first eight factors were considered a high-medium level of importance. In contrast, the remaining twenty-seven factors were regarded as a medium level of importance.

Table 5. Factors causing cost overrun of projects

\begin{tabular}{|c|c|c|c|c|}
\hline CRITERIA & MEAN & RII & RANK & LEVEL OF IMPORT ANCE \\
\hline Material shortage & 4.37 & 0.6282 & 1 & High-Medium \\
\hline Plant and equipment shortage & 4.33 & 0.6225 & 2 & High-Medium \\
\hline Acceleration required by the client & 4.31 & 0.6197 & 3 & High-Medium \\
\hline $\begin{array}{c}\text { Change of scope/material specification by } \\
\text { client }\end{array}$ & 4.29 & 0.6169 & 4 & High-Medium \\
\hline Mistakes during construction & 4.29 & 0.6169 & 4 & High-Medium \\
\hline Fluctuation in prices of raw materials & 4.20 & 0.6028 & 6 & High-Medium \\
\hline Shortage of workforce & 4.18 & 0.6000 & 7 & High-Medium \\
\hline Lack of skilled labour & 4.18 & 0.6000 & 7 & High-Medium \\
\hline Poor project management/ poor cost control & 4.16 & 0.5972 & 9 & Medium \\
\hline Contract awarded to the lowest bidder & 4.14 & 0.5944 & 10 & Medium \\
\hline Delays in work approval & 4.12 & 0.5915 & 11 & Medium \\
\hline Unstable cost of manufactured product & 4.12 & 0.5915 & 11 & Medium \\
\hline Incompetent subcontractor & 4.10 & 0.5887 & 13 & Medium \\
\hline Inaccurate cost estimates prepared & 4.08 & 0.5859 & 14 & Medium \\
\hline Additional work & 4.08 & 0.5859 & 14 & Medium \\
\hline $\begin{array}{c}\text { Breakdowns of construction plant \& } \\
\text { equipment }\end{array}$ & 4.08 & 0.5859 & 14 & Medium \\
\hline Incorrect planning & 4.06 & 0.5831 & 17 & Medium \\
\hline Increase in labour cost & 4.06 & 0.5831 & 17 & Medium \\
\hline The gap between design and tendering & 4.02 & 0.5775 & 19 & Medium \\
\hline Poor site management & 4.02 & 0.5775 & 19 & Medium \\
\hline Delay of drawings and site instructions & 4.00 & 0.5746 & 21 & Medium \\
\hline Inappropriate procurement & 4.00 & 0.5746 & 21 & Medium \\
\hline The high cost of machinery & 3.98 & 0.5718 & 23 & Medium \\
\hline Inappropriate government policies & 3.98 & 0.5718 & 23 & Medium \\
\hline Contractor's financial difficulties & 3.98 & 0.5718 & 23 & Medium \\
\hline Project complexity & 3.96 & 0.5690 & 26 & Medium \\
\hline Design and documentation issues & 3.96 & 0.5690 & 26 & Medium \\
\hline Delays in inspection and testing of work & 3.92 & 0.5634 & 28 & Medium \\
\hline Labour (human) resource & 3.90 & 0.5606 & 29 & Medium \\
\hline Contractor's workload & 3.88 & 0.5577 & 30 & Medium \\
\hline Material procurement & 3.88 & 0.5577 & 30 & Medium \\
\hline Slow decision making & 3.80 & 0.5465 & 32 & Medium \\
\hline Client's late contract award & 3.71 & 0.5324 & 33 & Medium \\
\hline Monthly payment difficulties & 3.61 & 0.5183 & 34 & Medium \\
\hline Waiting for information & 3.57 & 0.5127 & 35 & Medium \\
\hline
\end{tabular}




\section{Findings and Discussion}

\subsection{Shortage of Material $(\mathrm{RII}=\mathbf{0 . 6 2 8 2})$}

Shortage of material was ranked the highest out of the total factors, and it was categorized under external factor. Most of the respondents strongly agreed that it was a significant factor. The mean of this factor was "4.37" while RII was "0.6282". The result suggests that increase in cost is due to shortage of material which leads to the waste of time. Thereby leading to the extension of the completion time, which in turn brings about an increase in the overhead. In a previous study conducted in Ghana, the shortage of material was ranked as number 13 [10]. However, another study conducted in Nigeria showed that this factor was ranked as number 2 [2]. Therefore, the respondents in Nigeria and Sarawak strongly agree that a shortage of material will result in a cost overrun of the project. Also, another study conducted in the western part of Malaysia showed that the shortage of material was ranked number 4 [7]. Therefore, the respondents in the western part of Malaysia and the present study were firmly in agreement that this factor may lead to cost overrun in the construction industry. Hence, the respondents in the present study and previous studies all have the same opinion. However, the ranking of the previous study conducted in Ghana differed significantly with the present study. This difference can be attributed to the difference in culture and working environment of both countries.

\subsection{Shortage of Plant and Spare Parts of Equipment $(\mathrm{RII}=\mathbf{0 . 6 2 2 5})$}

Shortage of plant and spare parts of equipment was ranked second out of the total factors, and this factor was categorized under external factor. The mean of this factor was "4.33" while RII was "0.6225". Most of the respondents strongly agreed that this factor was one of the significant factors. The shortage of plant and spare parts of equipment might cause a delay in work, especially where the spare parts in question need to be imported. Thus the plant will remain dormant until the spare parts are replaced. Hence, the progress of work would be significantly hampered to the detriment of the project. The previous study conducted in Ghana showed that a shortage of plant and spare parts of equipment was one of the factors causing cost overrun of the project. The result of this factor was ranked $13^{\text {th }}$, which was considered to be moderate [10]. However, the result of the present study showed that a shortage of plant and spare parts of equipment was significant. Most of the respondents strongly agreed that this factor had the most significant influence on the cost, and it was ranked ${ }^{\text {second }}$. Hence, the respondents in the present study and previous studies have different perception due to the differences in location and culture.

\subsection{Acceleration Required by Client $(\mathrm{RII}=\mathbf{0 . 6 1 9 7})$}

Acceleration required by the client was the third out of the total factors. However, it was categorized under client-related factors. The mean of this factor was "4.31" while RII was "0.6197". Most of the respondents agreed that the client's request to speed up the construction work would result in a cost overrun. The workers shall work overtime or have a night shift to work overnight when the client's request is urgent, and so speeding up the construction period requires crashing activities and getting more workers. The cost incurred for working overtime may result in a cost overrun of the project. The previous study conducted in Asian countries such as South Korea, Hong Kong, Taiwan, Sri Lanka, Vietnam, Malaysia, Singapore and other countries showed that acceleration required by the client was one of the factors causing cost overrun of project work. However, speeding up the construction by the client in previous studies was ranked $12^{\text {th }}[12]$. Most of the respondents in the present study believed that acceleration required by the client was significant, and it was ranked third. Hence, there is a divergent opinion among researchers on this factor.

\subsection{Change in the Scope of Work or Specification of Materials by Client $(\mathrm{RII}=\mathbf{0 . 6 1 6 9})$}

Change of the scope of work by the client was ranked fourth. Besides, it was categorized under client-related factors. The mean of this factor was "4.29" while RII was "0.6169". Most of the respondents agreed that the changing scope of work or changes in the specification of materials influenced the cost of the project. In other words, variation means including or omitting part of the work. Also, issuing variation after the completion of that part of the work, it might cause the contractor to demolish the existing work and reconstruct. The completion date will have to be extended due to the variation order, and the additional cost will result in cost overrun of the project.

Previous studies conducted in Nigeria and Uganda showed that variation was a significant factor causing cost overrun of projects and was ranked the first $[2,13]$. Another study conducted in South Africa also showed that this factor was a significant factor causing cost overrun of projects, and it was ranked number two [9]. However, another study conducted in Asian countries such as South Korea, Hong Kong, Taiwan, Sri Lanka, Vietnam, Malaysia, Singapore, and other countries ranked this factor in the $9^{\text {th }}$ position [12]. The result of the present study also showed that this factor had an influence on cost, and it was ranked fourth. Hence, the respondents in the present study and previous study do have similar perception and opinion. 


\subsection{A Mistak5e during Construction $(\mathrm{RII}=\mathbf{0 . 6 1 6 9})$}

An error during construction was ranked $5^{\text {th }}$ out of the total factors, and it was categorized under contractor related factors. The mean of this factor was "4.29" while RII was "0.6169". Most of the respondents agreed that a mistake during construction due to the contractor's fault would result in a cost overrun. If the contractor fails to execute the work per the contract or install unapproved material, it may lead to the demolition of the work, and then be reworked. This rework would invariably hinder the progress of work and subsequently result in a cost overrun.

Previous studies conducted in Uganda and Asian countries such as South Korea, Hong Kong, Taiwan, Sri Lanka, Vietnam, Malaysia, Singapore and other countries showed that mistakes during construction were one of the factors causing cost overrun of projects. However, it was ranked $18^{\text {th }}$ in Asian countries, while Uganda ranked it $14^{\text {th }}[12,13]$. In another study conducted in Ghana, this factor was ranked $22^{\text {nd }}$; this suggests that this factor is not severe [10]. Nevertheless, the respondents of the present study agreed that mistakes during construction had an influence on cost, and it was considered to be a significant factor as it was ranked ${ }^{\text {fifth }}$. Hence, the respondents in the present study and previous studies have varied perception and opinion.

\subsection{Fluctuation in Prices of Raw Materials (RII $=$ 0.6028)}

Change in prices of raw materials was ranked 6th out of the total factors, and it was categorized under external factors. The mean of this factor was "4.20" while RII was "0.6028". Most of the respondents agreed that an increase in the cost of material would lead to cost overrun of projects. In construction projects, raw materials constitute a large amount of the construction cost. Therefore, the cost of construction will increase if the prices of raw materials increase.

Previous studies conducted in Pakistan and South Africa showed that the fluctuation in prices of raw material was ranked number one, which means it was considered highly significant $[9,11]$. Besides, another study conducted in Ghana showed that fluctuation in prices of raw material was ranked ${ }^{\text {sixth }}$ [12]. Another study which was held in Nigeria ranked it ${ }^{\text {second }}$ [2]. Therefore, there was a relationship between the previous studies and the present study that ranked it sixth. Hence, the respondents of the earlier studies and the present study may have similar perception and opinion. However, another study conducted in Asian countries such as South Korea, Hong Kong, Taiwan, Sri Lanka, Vietnam, Malaysia, Singapore and other countries showed that this factor was ranked $15^{\text {th }}$ [12]. This result may be due to the working environment and the perception of the respondents.

\subsection{Shortage of Manpower $(R I I=0.6000)$}

Shortage of workforce was ranked as the $7^{\text {th }}$ out of the total factors, and it was categorized under external factors. The mean of this factor was "4.18" while RII was "0.6000". Most of the respondents agreed that the shortage of workforce would lead to cost overrun. The construction work will face critical delay as a result of the inadequate workforce and will slow down progress on site.

Previous studies conducted in Ghana, Uganda, and South Africa showed that the shortage of workforce was considered to be moderate. At the same time, $t$ was ranked as $21^{\text {st }}, 17^{\text {th }}$ and $9^{\text {th }}$ in Ghana, Uganda and South African, respectively $[9,10,13]$. On the other hand, another study conducted in Nigeria showed that the shortage of workforce was ranked as $5^{\text {th }}$, which means it was considered to be significant [14]. The respondents of the present study believed that the shortage of workforce influenced cost. The result of the previous studies conducted in Ghana, Uganda, and South Africa was different from the present study due to the difference in location, perception, opinion and working environment. However, the result of the present study and previous study, which was conducted in Nigeria, was considered to be significant, meaning that the respondents may have similar perceptions and cultures.

\subsection{Lack of Skilled Labour $(\mathrm{RII}=\mathbf{0 . 6 0 0 0})$}

Shortage of skilled labour was ranked $8^{\text {th }}$ out of the total factors, and it was categorized under contractor related factors. The mean of this factor was "4.18" while RII was " 0.6000 ". Most of the respondents agreed that the lack of skilled labour would lead to cost overrun. Poor workmanship would lead to a reworking which may affect the quality and standard of the finished product.

The previous study conducted in Ghana showed that a lack of skilled labour was one of the factors causing cost overrun of projects. The position of this factor was $20^{\text {th }}$ [10] whereas it was ranked $3^{\text {rd }}$ in another study conducted in South Africa [9]. The respondents of the present study strongly agreed that the lack of skilled labour was a significant factor causing cost overrun of projects, and it was ranked eighth. Hence, the result of the previous study conducted in South Africa and the present study considered the lack of skilled labour to be significant, as respondents had similar perception. However, the result of the present study differs from the study conducted in Ghana. This difference might likely be due to cultural difference and opinion of the respondents in both studies.

\subsection{Poor Project Management and Poor Cost Control $(\mathrm{RII}=\mathbf{0 . 5 9 7 2})$}

Poor project management and poor cost control were ranked the $9^{\text {th }}$ out of the total factors, and it was categorized under client-related factors. The mean of this 
factor was "4.16" while RII was "0.5972". Most of the respondents agreed that poor project management and cost control would result in a cost overrun. Inappropriate planning during the design stage and construction stage may hinder the completion time of the project, estimated cost and the required quality. However, poor cost control during the design stage and construction stage may lead to the high cost of construction.

A previous study conducted in Pakistan showed that poor project management and poor cost control were ranked $5^{\text {th }}$ while another study conducted in Ghana ranked it $1^{\text {st }}[10,11]$. Besides, another study conducted in Nigeria showed that poor project management and poor cost control was ranked fourth [2]. Meanwhile, the previous study conducted in the western part of Malaysia showed that this factor was ranked ${ }^{\text {second }}$ [7]. At the same time, it was ranked $9^{\text {th }}$ in this study. This finding, therefore, suggests that the respondents of previous study and present study strongly consider this factor to be significant.

\subsection{Contract Awarded to the Lowest Bidder (RII = 0.5944)}

Contract awarded to the lowest bidder was in the $10^{\text {th }}$ position out of all the factors causing cost overrun, and it was categorized under client-related factors. The mean of this factor was "4.14" while RII was "0.5944". Most of the respondents agreed that the contract awarded to the lowest bidder would result in a cost overrun. The lowest bidder does not mean the better bidder as the lowest bidder may not often deliver quality work.

Previous studies conducted in Pakistan and Asian countries such as South Korea, Hong Kong, Taiwan, Sri Lanka, Vietnam, Malaysia, Singapore and other countries showed that contract awarded to lowest bidder was a significant factor causing cost overrun of projects. However, it was ranked $4^{\text {th }}$ in Pakistan and $1^{\text {st }}$ in Asian countries $[12,11]$ while it was ranked $8^{\text {th }}$ in the previous study conducted in South Africa [9]. Another study conducted in Ghana showed that this factor was ranked $14^{\text {th }}[9]$. In this present study, it was ranked $10^{\text {th }}$ which was similar to the study conducted in Asian countries.

\section{Conclusions}

This paper complements the existing body of knowledge on the factors causing cost overrun across the construction industries. A comparison of the findings of this paper and previous related studies on cost overrun suggest that the level of importance attached to each cost overrun factor depends on the perception of the respondents and their location. Since all the 35 cost overrun factors and their level of importance are presented in a table, the first ten factors have been discussed and compared with previous studies. This is not to say that the remaining twenty-five (25) factors are of less importance in Sarawak, Malaysia. The top ten factors are the shortage of material, shortage of plant and spare parts of equipment, acceleration required by the client, change of work scope or changes in material specification by the client, mistakes during construction, fluctuation in prices of raw materials, shortage of workforce, lack of skilled labour, poor project management and poor cost control and the contract awarded to the lowest bidder. The factors have been discussed and compared with previous studies. Consequently, the paper provides insight and enables the clients, contractors, project managers and other players in the construction projects on the factors that could cause cost overrun of construction projects. Once they are identified early, it can then be managed and mitigated at the inception. The analyzed data of this research were collected through a quantitative survey approach. This factor is considered a major limitation of this paper. Future research could interview with relevant players in the construction industry to obtain qualitative data on the causes of cost overrun. Besides, future research could examine other grades of contractors not considered in this study. Moreover, registered developer under Sarawak Housing and Real Estate Developer Association (SHEDA) can be taken into consideration to have a diverse perception of practitioners in the construction industry.

\section{Acknowledgements}

We are very grateful to the reviewers for their comments and constructive suggestions to improve this paper.

\section{REFERENCES}

[1] Y. A. Olawale and M. Sun. Cost and Time Control of Construction Projects: Inhibiting Factors and Mitigating Measures in Practice, Construction Management and Economics, Vol. 28, No. 5, 509-526, 2010.

[2] O. J. Ameh, A. A. Soyingbe, and K. T. Odusami. Significant Factors Causing Cost Overruns in Telecommunication Projects in Nigeria, Journal of Construction in Developing Countries, Vol. 15, No. 2, 49-67, 2010.

[3] B. Flyvbjerg, M. K. Holm, and S. L. Buhl. What Causes Cost Overrun in Transport Infrastructure Projects? Transport Reviews, Vol. 24, No. 1, 3-18, 2004.

[4] S. M. Ahmed, S. Azhar, and M. Castillo. Construction Delays in Florida: An Empirical Study, Florida: Florida International University, 2002.

[5] A. H. Memon, I. A. Rahman, M. R. Abdullah, and A. A. Abdu Azis. Factors Affecting Construction Cost in Mara Large Construction Project: Perspective of Project 
Management Consultant, International Journal of Sustainable Construction Engineering \& Technology, Vol. 1, No. 2, 41-54, 2010.

[6] I. A. Rahman, A. H. Memon, and A. T. Abd Karim. Significant factors causing cost overruns in large construction projects in Malaysia, Journal of Applied Sciences, Vol. 13, No. 2, 286-293, 2013.

[7] A. H. Memon, I. A. Rahman, and A. A. Abdul Azis. Time and Cost Performance in Construction Projects in Southern and Central Regions of Peninsular Malaysia, International Journal of Advances in Applied Sciences, Vol. 1, No. 1, 45-52, 2012.

[8] Z. Shehu, I. R. Endut, A. Akintoye, and G. D. Holt. Cost overrun in the Malaysian construction industry projects: A deeper insight, International Journal of Project Management, Vol. 32, No. 8, 1471-1480, 2014.

[9] L. Baloyi, and M. Bekker. Causes of Construction Cost and Time Overruns: The 2010 FIFA World Cup Stadia in South Africa, Acta Structilia, Vol. 18, No. 1, 51-67, 2011.

[10] Y. Frimpong, J. Oluwoye, and L. Crawford. Causes of Delay and Cost Overruns in Construction of Groundwater Projects in a Developing Countries: Ghana as a Case Study, International Journal of Project Management, Vol. 21, 321-326, 2003.

[11] N. Azhar, R. U. Farooqui, and S. M. Ahmed. Cost Overrun Factors in Construction Industry of Pakistan, First International Conference on Construction in Developing Countries, Karachi, Pakistan: Advancing and Integrating Construction Education, Research and Practice, 449-508, 2008.

[12] Y. I. Park, and T. C. Papadopoulou. Causes of Cost Overruns in Transport Infrastructure Projects in Asia, Built Environment Project and Asset Management, Vol. 2, No. 2, 195-216, 2012.

[13] R. Apolot, H. Arinaitwe, and D. Tindiwensi. Investigation into the Causes of Delays and Cost Overruns in Uganda's Public Sector Construction Projects, Journal of Construction in Developing Countries, Vol. 18, 33-47, 2013.

[14] R. F. Aziz. Factors Causing Cost Variation for Constructing Wastewater Projects in Egypt, Alexandria Engineering Journal, Vol. 52, No. 1, 51-56, 2013.

[15] S. Durdyev, S. Ismail, and N. A. Bakar. Factors Causing Cost Overruns in Construction of Residential Project: Case Study of Turkey, International Journal of Science and Management, Vol. 1, No. 1, 3-12, 2012.

[16] I. F. Olubunmi, and A. K. Olukanyin. An Evaluation of Success Factors of Foreign Construction Companies in Lagos State, International Journal of Science, Environment, Vol. 4, No. 2, 533-542, 2015.

[17] C. Bordat, B. G. McCullouch, S. Labi, and K. C. Sinha. An Analysis of Cost Overruns and Time Delays of INDOT Projects, West Lafayette: INDOT Division of Research, 2004.

[18] P. Akanni, A. Oke, and O. Akpomiemie. Impact of environmental factors on building, Housing and Building National Research Center (HBRC) Journal, Vol. 11, 91-97,
2014.

[19] A. Enshassi, J. Al-Najjar, and M. Kumaraswamy. Delays and cost overruns in the construction projects in the Gaza Strip, Journal of Financial Management of Property and Construction, Vol. 14, No. 2, 126-151, 2009.

[20] R. M. R. Raja Rafidah, A. M. Muhd Zaimi, S. Shaza Rina, A. I. Noor Akmal. Relative Importance Index of Sustainable Design and Construction Activities Criteria for Green Highway, Chemical Engineering Transactions, Vol. 63, 151-156, 2018

[21] R. Yehiel. Root-Cause Analysis of Construction-Cost Overrun, Journal of Construction Engineering Management, Vol. 140, No. 1, 04013039 1-10, 2014.

[22] A. M. Murat Gündüz, N. Yasemin, and O. Mustafa. Quantification of Delay Factors Using the Relative Importance Index Method for Construction Projects in Turkey, Journal of Management in Engineering, Vol. 29, No. 2, 133-139, 2013.

[23] D. Hemanta. Cost Overruns and Failure in Project Management: Understanding the Roles of Key Stakeholders in Construction Projects, Journal of Construction Engineering and Management, Vol. 139, No. 3, 267-279, 2013.

[24] S. T. Kometa, P. O. Olomolaiye, and F. C. Harris. Attributes of UK construction clients influencing project consultant's performance, Construction Management Economics, Vol. 12, No. 5, 433-443, 1994.

[25] M. Sambasivan, and Y. W. Soon. Causes and effects of delays in the Malaysian construction industry, International Journal of Project Management, Vol. 25, No. 5, 517-526, 2007.

[26] O. P. Akadiri. Development of a Multi-Criteria Approach for the Selection of Sustainable Materials for Building Projects, $\mathrm{PhD}$ Thesis, University of Wolverhampton, Wolverhampton, UK, 2011.

[27] S. O. Cheung, P. S. Wong, and T. W. Yiu. The Soft Power of Construction Contracting Organisations, New York: Routledge, 2015. 